\title{
EVALUATION OF IN VITRO ANTI-UROLITHIATIC ACTIVITY OF METHANOLIC EXTRACT OF CUCUMIS MELO SEEDS ON CALCIUM OXALATE CRYSTALS
}

\author{
R. SRIKARAN, S. SALIKA DULANJALI* \\ Department of Chemistry, Faculty of Science, University of Jaffna \\ Email: s.salikadulanjali@gmail.com
}

Received: 15 Oct 2018, Revised and Accepted: 10 Dec 2018

\section{ABSTRACT}

Objective: This in vitro study was carried out to evaluate the anti-urolithiatic activity of the methanolic extract of the Cucumismelo seeds on experimentally prepared calcium oxalate crystals which was prepared by the homogeneous precipitation method in the laboratory.

Methods: The crude extract was prepared by the soxhlet extraction method and the extraction was done until all the compounds get extracted into the solution and solvent was evaporated by rotary evaporator. Extracts were stored in an airtight light-resistant container at $4{ }^{\circ} \mathrm{C}$ in a refrigerator for further analysis.

Results: Seed extract of Cucumismelo showed maximum efficiencies in the dissolution of the calcium oxalate crystals. Cystone drug was used as the standard. This in vitro study has shown that the methanolic extract of the seeds of Cucumismelo has the potential anti-urolithiatic activity when compared with the standard.

Conclusion: This in vitro study has given the primary evidence that the extract of seeds of Cucumismelo has the anti-urolithiatic activity. In vivo studies can be carried out on the seed extract of Cucumismelo for further investigations.

Keywords: Anti-urolithiatic activity, Urolithiasis, Cucumismelo, In vitro, Methanolic extract

(c) 2019 The Authors. Published by Innovare Academic Sciences Pvt Ltd. This is an open-access article under the CC BY license (http://creativecommons.org/licenses/by/4.0/) DOI: http://dx.doi.org/10.22159/ijcpr.2019v11i1.31994

\section{INTRODUCTION}

Stone formation in the human body is the oldest and very painful urologic disorder which forms due to the change in lifestyle and dietary factors. Formation of stones or calculi is called as the lithiasis which approximately occurs $12 \%$ of global population. If the stones are formed in the kidney is called as nephrolithiasis and the formation of calculi in the urinary bladder, ureter or anywhere in the urinary tract is known as urolithiasis [1].

The word "Urolithiasis" is derived from Greek as "Urone" for urine and "Lithos" for stones. Urolithiasis is one of the major diseases of the urinary tract with increasing prevalence and incidence in the world. This urologic disorder occurs in approximately $12 \%$ of the global population and it is more common in male than female [2]. Its recurrence rate is high $14 \%$ after one year, $25 \%-31.5 \%$ after five years, $49 \%-52 \%$ after ten years, $72 \%$ after twenty years [3].

This kidney stone formation is a multistep process which is the result from the influences of epidemiological, biochemical and genetic risk factors [4]. The formation of the kidney stones involves several phytochemical events beginning from the crystal nucleation, aggregation, and end with retention within urinary tract [5]. Before the crystal nucleation supersaturation will be take place. Urinary $\mathrm{P}^{\mathrm{H}}$, Ionic strength, Solute concentration and a complexion like factors are affected on the supersaturation process [6].

According to the National Institution of Health of the United State, approximately one person in ten develops urinary stones during their lifetime [7]. Although such data regarding Sri Lanka are not available according to Abeygunasekara 2011[8]. But some studies have suggested a high intake of fluoride act as promoters for the formation of kidney stones. When the fluoride level in drinking water is rise from 3.5 to $4.9 \mathrm{ppm}$ prevalence of urolithiasis is 4.6 times higher than the normal condition. Water wells in dry zone areas in Sri Lanka such as Anuradhapura, Polonnaruwa, and Ampara contain fluoride content greater than $3 \mathrm{ppm}$.

Treatments for the urolithiasis are varies depending on the composition, location, patient factors and size of the stones in the urinary tract. For the treatments of small calculi can be managed by consuming a considerable amount of drinking water for a day also by treating with the $\propto$-blockers to flushing out the small stones (Medical expulsion therapy). For the treatment of large stones can be done by using extracorporeal shock wave lithotripsy (ESWL) which break the large stones into tiny pieces. This therapy is high expensive and may damage to the urinary system [9]. Also, they do not prevent the formation of new stones [10].

Using medicinal plants for the treatment of the urolithiasis is not only simple, less side effects but also cost-effective. According to the World Health Organization (WHO) about $70 \%$ of global populations are using indigenous medicines to cure various diseases.

Lots of medicinal plants have been using as traditional health care system from the centuries in folk and ayurvedic treatments. Some medicinal plants have been reported which use for the treatments of urolithiasis in folk and ayurvedic medical practices and they have shown a significant effect on in vitro and in vivo anti-urolithiatic activity in researches which have been done. So, this study was carried out based on the medicinal plants which selected for the evaluation of in vitro antiurolithiatic that have been reported to have anti-urolithiatic property according to the ayurvedic medicinal system in Sri Lanka and in this study calcium oxalate was prepared by mixing calcium chloride dihydrate and sodium oxalate in laboratory condition by homogenous precipitation method. Even though differences between naturally occurring kidney stones and experimentally prepared stones have existed, the study was carried out as an experimental study or as the first step for the drug discovery. If there any significant results are obtained, the study can be proceeded by using stones removed from the patients who affected by the kidney stones.

\section{MATERIALS AND METHODS}

\section{Collection of plant materials}

The fruits of Cucumismelo were collected in the month of October 2017 from the Thirunelvely local market area and farm areas in kondavil, Jaffna, Sir Lanka. The materials were authenticated by the department of botany, University of Jaffna. The seeds were removed from the strips and 
were washed thoroughly with the tap water followed by distilled water. Then seeds were shade dried for three weeks and were pulverized.

\section{Reagents used}

Methanol, Sodium oxalate, Tris buffer, Calcium chloride, Potassium permanganate $\left(\mathrm{KMnO}_{4}\right)$, Conc. Sulphuric acid $\left(\mathrm{H}_{2} \mathrm{SO}_{4}\right)$, Mayer's reagent, Wagner's reagent.

\section{Extraction process}

Methanolic extract was obtained by using $200 \mathrm{~g}$ of powdered seeds and using $400 \mathrm{ml}$ of methanol in soxhlet apparatus at $64{ }^{\circ} \mathrm{C}$ temperature until all the compounds were extracted into the solvent. The extract was evaporated and concentrated by using rotary evaporator at $45^{\circ} \mathrm{C}$ temperature. Further, dried extract was stored in an airtight, light-resistant container at $4{ }^{\circ} \mathrm{C}$ in the refrigerator for further analysis [11].

Preparation of calcium oxalate crystals by homogeneous precipitation method

Calcium Chloride dihydrate (4.41g) dissolved in distilled water and Sodium Oxalate (4.02g) dissolved in $2 \mathrm{~N}$ Sulphuric acid were taken into separate beakers and both solutions were mixed together to react with stirring until Calcium oxalate precipitate formed. Excess Sulphuric acid was removed by washing with Ammonia solution and

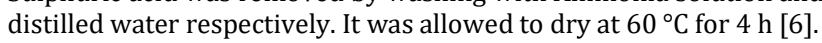

\section{Preparation of semi-permeable membranes from farm eggs}

The apex of eggs was punctured by a glass rod to remove the entire content. Empty egg shells were washed thoroughly with distilled water and placed in a beaker consisting $2 \mathrm{M} \mathrm{HCl}$ for an overnight which caused complete decalcification. Then membranes were washed with distilled water and they were placed in ammonia solution for neutralization of acid traces in the moistened condition for a while. Then they were rinsed with distilled water and Stored in a refrigerator at a $\mathrm{pH}$ of 7-7.4 [6].

\section{Evaluation of anti-urolithiatic activity by the titrimetric method}

Totally 9 semi-permeable membranes were prepared and exactly $5 \mathrm{mg}$ of calcium oxalate crystals and four different concentrations $(10 \mathrm{mg}, 20$ $\mathrm{mg}, 30 \mathrm{mg}, 40 \mathrm{mg}$ ) of extracts and standard (Positive control) were placed in separate membranes and they were sutured carefully. One sample which contained calcium oxalate crystals only was used as the negative control. These were allowed to suspend in the separate conical flasks which containing $100 \mathrm{ml}$ of tris buffer solution $(0.1 \mathrm{M})$. All the conical flasks were incubated at $37{ }^{\circ} \mathrm{C}$ for $7 \mathrm{~h}$. Then the content in the semi-permeable membrane was transferred into a test tube and $2 \mathrm{ml}$ of $1 \mathrm{~N}$ sulphuric acid was added. The resulting mixture was titrated against the standard $\mathrm{KMnO} 4$ solution until the light pink colour was observed. This whole procedure was repeated three times to get the accurate results. The dissolution percentages of the calcium oxalate crystals were calculated for each sample to evaluate the activity [6].

\section{Phytochemical analysis}

Chemical tests were carried out on the plant extract using standard procedures to identify the constituent molecules as described by sofowara and co-workers. Aqueous and ethanolic extracts of Cucumismelo seeds were prepared. Then phytochemical analysis was carried out on these plant extracts.

\section{RESULTS AND DISCUSSION}

The formation of urine stones is a complex process which has several steps such as supersaturation, nucleation, growth, aggregation, and retention [12]. High intake of dietary calcium may inhibit the formation of kidney stones rather than causing the stones [13]. Phytochemicals such as Terpenoids, Tannins, alkaloids, and saponins can be responsible for the anti-urolithiatic activity of the plant extracts. Some phytochemicals which may be effective for the dissolution of the calcium oxalate kidney stones are Kaempferol-3-rhamnoside and Kaempferol-3rhamnogalactoside, triterpenes such as botulin and tannins [14].

In this study, the anti-urolithiatic activity of the methanolic extract of Cucumismelo seeds was compared with the standard drug cystone. Plant extract shows a considerable amount of antiurolithiatic activity as the standard cystone drug.

The dissolution percentage by the extract of Cucumismelo seed at $10 \mathrm{mg}$, $20 \mathrm{mg}, 30 \mathrm{mg}$ and $40 \mathrm{mg}$ concentrations were $67.5( \pm 0.525) \%$, $77.1( \pm 0.094) \%, 80.9( \pm 0.340) \%, 85.9( \pm 0.573) \%$ respectively. Dissolution percentage by the standard drug cystone at $10 \mathrm{mg}, 20 \mathrm{mg}, 30 \mathrm{mg}$, and 40 mg were found to be as 59.6( \pm 0.432$) \%, 64.2( \pm 0.163) \%, 74.8( \pm 0.283) \%$ and $78.3( \pm 0.249) \%$ respectively. Dissolution percentage for the control test was $22.1( \pm 0.249) \%$. Phytochemical analysis of the ethanolic and aqueous extracts of the Cucumismelo shows the positive results for the presence of alkaloids terpenoids. The research findings revealed that even though cystonepolyherbal drug has high dissolution ability, methanolic extracts of Cucumismelo seeds also have considerable antiurolithiatic activity.

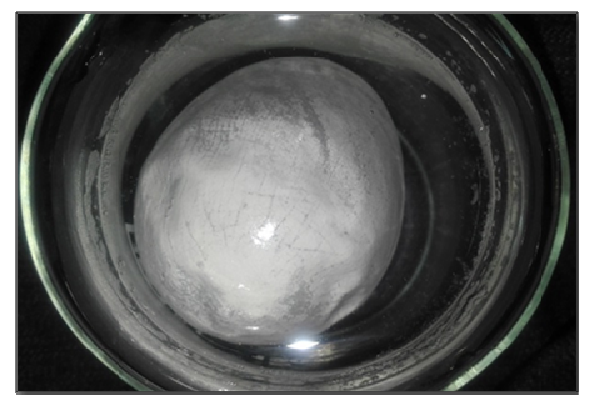

Fig. 1: Decalcified eggs

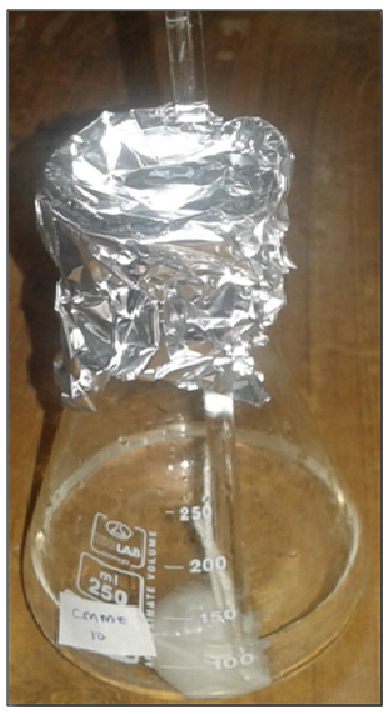

Fig. 2: In vitro experimental model setup

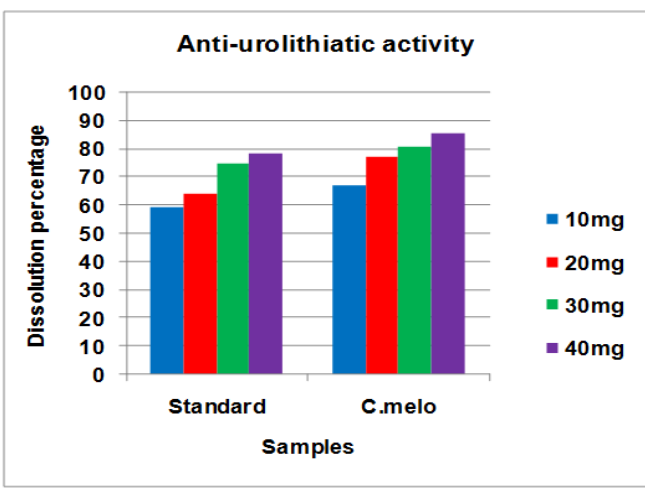

Fig. 3: Anti-urolithiatic activity of the standard and sample 
Table 1: Preliminary phytochemical screening

\begin{tabular}{ll}
\hline Test name & Aqueous/Ethanolic extract \\
\hline Mayer's test & + \\
Wagner's test & + \\
Saponin & + \\
Libermann-Budhard's test & - \\
Phenolic groups & - \\
Flavonoids & - \\
Terpenoids & + \\
Phlobatannin & - \\
\hline
\end{tabular}

$(+)$ indicate the presence and (-) indicate

\section{CONCLUSION}

Humankind is known as suffering from urinary stone diseases which are a common and most painful disease found in all around the world. Uses of pashanabheda plants in the treatments of the urinary calculi are most popular in the Ayurvedic and folk medicines. Cucumismelo plant was selected according to the literature found in the Sri Lankan ayurvedic medicines. Methanolic extract of the Cucumismelo seeds has the high anti-urolithiatic activity compared to the standard polyherbal drug cystone. This research work has given the primary evidence for the presence of anti-urolithiatic property of the seeds of Cucumismelo.

\section{ACKNOWLEDGMENT}

I am extremely thankful to my research supervisor Dr. R. Srikaran, senior lecturer, Department of chemistry, Faculty of science, University of Jaffna. I am extremely thanks to technical officers, laboratory staff for their kind support. My special thanks to my beloved parents for their blessing and encouragement which helped me lot.

\section{AUTHOR'S CONTRIBUTIONS}

All authors have contributed equally

\section{CONFLICT OF INTERESTS}

Declare none

\section{REFERENCES}

1. Ram J, Moteriya P, Chanda S. An overview of some promising medicinal plants with in vitro anti-urolithiatic activity. J Pharm 2015;5:23-8.

2. Vijaya T, Sathish Kumar M, Ramarao NV, Narendra Babu A, Ramarao N. Urolithiasis and its causes-short review. J Phytopharmacol 2013;2:1-6.
3. Pethiyagoda A, Pethiyagoda K. Descriptive evaluation of ureteric urolithiasis between genders. Int J Sci Res Publications 2016;6:47-50.

4. Atodariya U, Barad R, Upadhyay S, Upadhyay U. Antiurolithiatic activity of Dolichosbiflorus seeds. J Pharmacogn Phytochem 2013;2:209-13.

5. Niharika M, Himabindu J, Ramanjaneyalu K. Evaluation of in vitro antiurolithiatic activity of Tridaxprocumbens. Int J Sci Res 2018;7:93-8.

6. Jha R, Ramani P, Patel D, Desai S, Meshram D. Phytochemical analysis and in vitro urolithiatic activity of leaves (DC) Baker. J Med Plants Studies 2016;4:18-22.

7. WWW.urologyspecialistsatlanta.com. [Last accessed on 10 Aug 2018].

8. Abeygunasekara AM. Urinary stone disease in Sri Lanka. Ceylon Medical Journal 2011;29:41-3.

9. Perera ND, Perera JS. The role of extracorporeal shock wave lithotripsy in renal calculi. Sri Lanka J Surgery 2014;31:6-12.

10. Sharma D, Dey YN, Sikarwar I, Sijoria R, Wanjari MM, Jadhav AD. In vitro study of aqueous leaf extract of Chenopodium album for inhibition of calcium oxalate and brushite crystallization. Egyptian J Basic Appl Sci 2016;3:164-71.

11. Akinyeye AJ, Solanke EO, Adebiyi IO. Phytochemical and antimicrobial evaluation of leaf and seed of Moringaoleifera extracts. Int J Res Med Health Sci 2014;4:2307-83.

12. Bijauliya RK, Alok S, Jain, S. K., Singh, V. K. and Singh, D., 2017. Herbal and allopathic medicine for kidney, gallbladder, and urinary stones: a review. Int J Pharm Sci Res 1935. p. 8.

13. Johri N, Cooper B, Robertson W, Choong S, Rickards D, Unwin R. An update and practical guide to renal stone management. Nephron Clin Practice 2010;116:c159-71.

14. Kumar BN, Kumar GK, Srinivasa V, Syed Bilal. A review on urolithiasis: Int J Universal Pharm Life Sci 2012;2:269-80. 